\section{Shell Movements of a Wood Boring Bivalve}

Some bivalves of the super-family Adesmacea are known to penetrate wood by means of mechanical action of the shell valves. The process has been described by various authors, the most comprehensive account being that of Miller ${ }^{1}$ for Teredo. Although rocking movements of the shell valves about a dorso-ventral axis are known to be important in penetration of this substratum ${ }^{2}$, there seem to be no records for any wood boring bivalve of the type and frequency of the shell movements involved.

We have recorded and filmed the shell movements of Xylophaga dorsalis Turton. Adult specimens of this bivalve were obtained from laminated timber test panels exposed at Keppel Pier, Millport, on August 9, 1966, and recovered in August 1967. Xylophaga was found readily boring through such laminated panels, unlike eertain species of Teredo whose burrows do not extend through the laminations. By careful separation of the individual laminae specimens of $X y$ lophaga were exposed without any damage and with minimum interference to the animal in the burrow. Specimens removed from the burrows and replaced in smooth cylindrical holes drilled in pieces of cork soaked in sea water were also found to resume boring activity. Records of movements of the shell valves were obtained on a pen recorder (E. and M. Instrument Co. Ine., 'Physiograph'), using an isometric myograph, attached by fine thread to the posterior wing of one valve of the shell.

During several days, when the animals were kept and observed in a continuous flow of sea water, the shell movements chiefly consisted of irregularly spaced periods of vigorous activity (Fig. 1) interspersed with periods of relative inactivity, during which only slight or infrequent larger movements wore made. Stoppage of water flow resulted in a slowing down or even cessation of activity
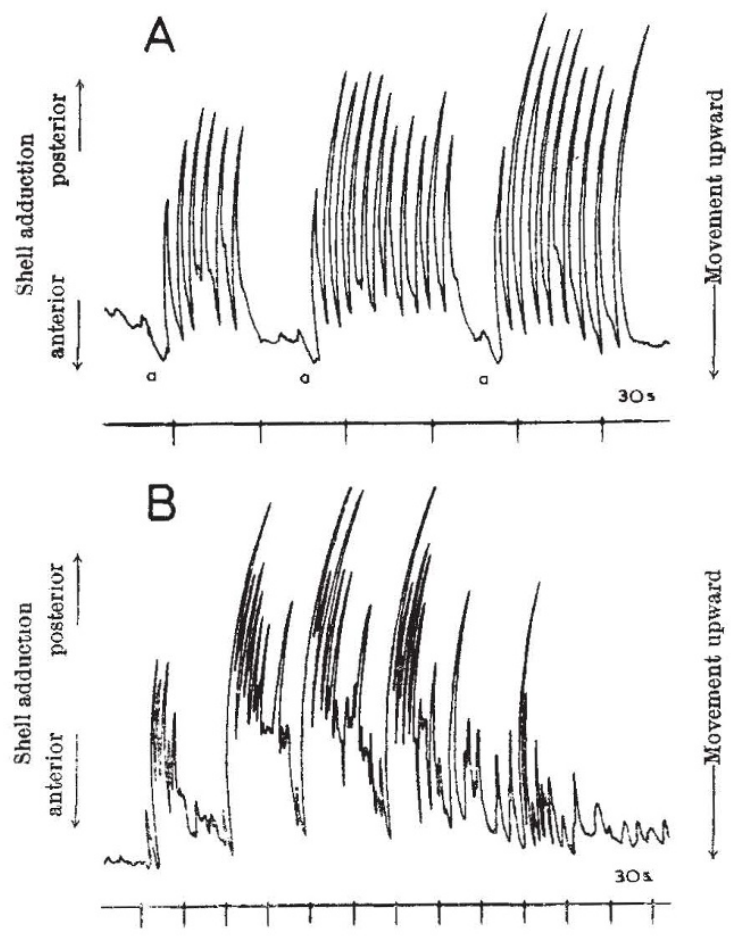

Fig. 1. Two extracts from a recording of the activity of the wood boring bivalve $X$ ylophaya dorsalis. $A$, Three cycles of boring activity comprising six, eleven and nine rocking movements of the shell valves respectively, caused by successive contraction of the posterior and anterior adductor muscles. Before each group of rocking movements the foot is and the shell is then immediately drawn downwards to the base of the burrow. $B$, One complete group of boring cycles showing the variation in number and strength of the rocking movements involved. which was, however, rapidly resumed when the water flow was restarted. During the periods of activity characteristic shell movements were recorded which differed from any hitherto recorded from bivalves, and which are clearly associated with enlargement of the burrow. The shell is drawn towards the blind end of the burrow by the contraction of the pedal retractor muscles, the sole of the foot being attached to the walls of the burrow by mucus secretion. The shell valves then rock about a dorso-ventral axis by the alternate contraction of, first, the posterior and then the anterior adductor muscles (Fig. $1 B$ ), the umbones and ventral articular knobs forming a fulerum for this movement. During the contraction of the posterior adductor muscles the denticulate ridges sculpturing the anterior outer faces of the shell valves are drawn across the walls of the burrow with an effective abrasive action. Considerable variation was recorded in the number of alternate contractions of the adductor muscles comprising each boring cycle as well as in the strength of adduction of the shell valves. Small rotatory movements of the animal were also evident (not shown in the recordings) occurring between the series of rocking movements.

These recordings illustrate the specialization of the movements involved in boring into wood in the Ad эsmacea. Each series of rocking movements is apparently homologous to the boring cycle of the less specialized Pholadidae, which in turn has characteristies in common with the digging cycle of those species which burrow into soft substrata ${ }^{3}$. The movements recorded therefore fully support the view that rock boring in this group has evolved as a specialization of a deep-burrowing habit ${ }^{4}$.

The mechanisms of boring in Xylophaga and the relationships of these to burrowing and boring in other bivalves will be reported in greater detail elsewhere. This work was carried out during the tenure of a Royal Society and Nuffield Foundation Commonwealth Bursary held by one of us (N. B. N.).

The Marine Station,

Alan D. Anselt

Millport,

Isle of Cumbrae, Scotland.

\section{N. Batakrishnan NAIr}

Oceanographic Laboratory,

University of Kerala,

Ernakulam, India.

Received September 4, 1967.

${ }^{1}$ Miller, R. (., Univ, Calif. Publs, Zool., 26, 41 (1924).

Morton, J. F in Physiology of the Mollusca (edit. by Wilbur, K. M.. and Yonge, C. in Physiology of the Mollusca (edit.

Nair, N. B., and Ansell, A. D., Proc. R. Soc. (in the press).

4 Yonge, C. M., Research, 4, 162 (1951).

\section{Virus-like Particles in a Weed Mould growing on Mushroom Trays}

DURING investigations of virus diseases of the cultivated mushroom, Agaricus bisporus (Lange) Sing., samples were collected of a species of Plicaria which is probably similar to Plicaria fulva described by Schneider ${ }^{1}$ [synonym Peziza atrovinosa Cooke and Gerard]. This fungus is considered to be the perfect stage of Botrytis crystallina (Bon.) Sacc. ${ }^{2}$, the brown mould. Apothecia of $P$. fulva, collected from various mushroom farms, were tested for the presence of virus particles to investigate the possible role of this weed mould in the spread of viruses of eultivated mushrooms.

Purification was carried out by a method found satisfactory for mushroom viruses ${ }^{3}$ : about $10 \mathrm{~g}$ of apothecia was homogenized for $2 \mathrm{~min}$ in a Waring blender with $30 \mathrm{ml}$. of 0.033 molar phosphate buffer containing $0 \cdot 1$ per cent thioglycollic acid. adjusted to $p \mathrm{H}$ 6.8. Samples of 